\title{
PENGARUH PELATIHAN MOTIVASI BERPRESTASI TERHADAP PENINGKATAN EFIKASI DIRI PADA MAHASISWA KEDOKTERAN DI UNIVERSITAS “Z”
}

\author{
Shinta Putri Megawati \\ Pusat Psikologi Terapan Metamorfosa, Yogyakarta \\ Email: shintaputri31@yahoo.co.id
}

\begin{abstract}
This study was aimed understand the influence of Achievement Motivation Training in increase self efficacy of medicine students in Islamic University of Indonesia. Research design of this study was one-group multiple pre-test post-test design on quasi experiment with 173 subjects of experimental group in 2 days training. Data collected by self-efficacy scale from Bandura's theory (1997). Analysis of the data used non parametrical statistic by Wilcoxon Signed-Rank Test. Results showed that Z-score was -10.058 $(p<0.000)$.
\end{abstract}

Keywords: Achievement Motivation Training, self-efficacy

\section{ABSTRAK}

Penelitian ini bertujuan untuk mengetahui pengaruh Pelatihan Motivasi Berprestasi (PMB) terhadap peningkatan efikasi diri pada mahasiswa kedokteran di Universitas "Z". Desain pelatihan yang digunakan adalah one-group multiple pre-test - post-test design pada metode quasi eksperimen dengan 173 subjek di kelompok eksperimen selama dua hari pelatihan. Data dikumpulkan menggunakan skala efikasi diri berdasarkan teori Bandura (1997). Teknik analisis statistik yang digunakan adalah non parametrik, yaitu Wilcoxon Signed-Rank Test. Hasil menunjukkan bahwa PMB terbukti dapat meningkatkan efikasi diri , dengan $Z=-10.058(p<0,000)$.

Kata Kunci: Pelatihan motivasi Berprestasi, Efikasi Diri

Mahasiswa adalah status yang disandang oleh seseorang yang belajar di perguruan tinggi dengan harapan dapat menjadi calon-calon intelektual. Bila di runtut kembali, banyak fakta sejarah yang membuktikan betapa luar biasa peran dari mahasiswa. Salah satunya adalah peran pemuda yang terus mendesak Ir. Soekarno untuk segera memproklamasikan kemerdekaan. Yang lain adalah dideklarasikannya sumpah pemuda yang menginspirasi kemerdekaan Indonesia.
Kiprah yang luar biasa ini menjadikan mahasiswa mendapatkan julukan sebagai agent of change atau pembawa perubahan di masyarakat. Bahkan mahasiswa memiliki peran lain, yaitu sebagai iron stock, yang harapannya kelak mahasiswa mampu menjadi generasi penerus yang akan memimpin bangsa. Tentu mahasiswa yang menyadari akan perannya ini, terlahir dari perguruan tinggi yang unggul dengan visi dan misinya. Salah satu perguruan tinggi tersebut adalah Universitas "Z" dengan visi sebagai 
rahmatan lil 'alamin yang memiliki komitmen pada kesempurnaan (keunggulan), risalah Islamiyah, di bidang pendidikan, penelitian, pengabdian masyarakat dan dakwah, setingkat universitas yang berkualitas di negara-negara maju (https://www.uii.ac.id/visi-dan-misi/).

Universitas " $Z$ " dari tahun ke tahun semakin banyak diminati. Hal ini terbukti dengan semakin banyaknya pendaftar yang ingin masuk ke Universitas " $Z$ ". Tahun 2015 jumlah pendaftar yaitu 27.654, sedangkan tahun sebelumnya berjumlah 26.248. Ini artinya, terjadi peningkatan sebanyak $5.36 \%$. (Ma'arif, 2015). Prodi yang paling diminati adalah Kedokteran (Firmansyah, 2015).

Fakta di atas menunjukkan betapa besar antusias para pemuda untuk mengabdikan diri memajukan dan memperbaiki kesehatan masyarakat Indonesia. Akan tetapi, tidak sedikit mahasiswa yang sudah masuk kuliah justru kehilangan motivasi karena terlalu banyaknya stressor yang diterima (Rumiani, 2006). Mahasiswa kedokteran perlu beradaptasi dengan kurikulum dan proses belajar yang berbeda saat di Sekolah Menengah Atas. Tahapan pendidikan sarjana kedokteran terdiri atas 24 Blok dengan total SKS sebanyak 137 (Miladiyah dkk, 2010).

Oleh karena itu, mahasiswa perlu menyiapkan diri untuk menyongsong kurikulum yang baru ini. Ditambah lagi metode pembelajaran di Fakultas Kedok- taran sangat beragam, dari diskusi tutorial, praktikum, karya tulis ilmiah hingga keterampilan medik. Mahasiswa kedokteran juga memiliki banyak tugas kuliah dan deadline yang sangat padat. Hal ini menjadi tantangan tersendiri bagi para mahasiswa kedokteran untuk melakukan penyesuaian diri agar menemukan satu titik temu antara kondisi diri sendiri dan tuntutan lingkungan (Mu'tadin, 2002). Saat mahasiswa memiliki keyakinan yang cukup besar akan kemampuannya menyelesaikan tugas studi, ini berarti mereka memiliki efikasi diri yang positif.

Efikasi diri adalah keyakinan seseorang mengenai kemampuannya untuk memobilisasi motivasi, sumber daya kognitif, dan tindakan yang diperlukan agar berhasil melaksanakan tugas dalam konteks tertentu (Bandura, dalam Luthans 2006). Penerapan konsep efikasi diri pada berbagai aspek prestasi para mahasiswa memperlihatkan bahwa efikasi diri memengaruhi pilihan mahasiswa terhadap aktivitas-aktivitas yang dilakukan (Santrock, 2007).

Efikasi diri memegang peran yang sangat penting dalam kehidupan seharihari. Seseorang akan mampu menggunakan potensi dirinya secara optimal bila efikasi dirinya mendukung (Rustika, 2012). Efikasi diri adalah keyakinan seseorang mengenai kemampuannya dalam melaksanakan tugas untuk mencapai hasil tertentu (Slamet dkk, 2014). Terdapat tiga 
dimensi dalam efikasi diri, yaitu dimensi level sebagai keyakian pada tindakan, dimensi kekuatan atau kemampuan untuk bertahan dan dimensi generalisasi atau kemampuan yang ditunjukkan untuk berhasil (Bandura, 2006)

Menurut Bandura (1997), efikasi diri dibentuk oleh empat sumber informasi, yaitu pengalaman berhasil, pengalaman vikarius/seolah mengalami sendiri, persuasi sosial dan keadaan emosi/fisik. Pengalaman berhasil merupakan sumber informasi efikasi yang paling berpengaruh karena mampu memberikan bukti nyata tentang keberhasilan yang telah dicapai. Sedangkan pengalaman vikarius diperoleh melalui model sosial yang diamatinya. Efikasi diri juga dapat diperoleh dan diperkuat melalui persuasi sosial. Hal ini berkaitan dengan rasa percaya kepada pemberi persuasi dan sifat realistik dari apa yang dipersuasikan. Di sisi lain, keadaan emosi/fisik dalam mengikuti suatu kegiatan akan berpengaruh pada tingkat efikasi diri (Wijaya \& Pratitis, 2012).

Baron dan Byrne (2004) menyatakan bahwa individu dengan efikasi diri akademis positif memiliki kemampuan untuk melakukan kegiatan perkuliahan, pengaturan aktivitas belajar, dan memenuhi harapan. Penelitian lain menunjukkan bahwa efikasi diri yang baik memberikan pengaruh pada peningkatan IPK (indeks prestasi kumulatif) mahasiswa
(Vuong, dkk., 2010). Terdapat beberapa faktor yang mampu memengaruhi efikasi diri di antaranya persuasi sosial dan keadaan emosi (Wijaya \& Pratitis, 2012). Kedua hal tersebut dapat diberikan melalui kegiatan PMB (Pelatihan Motivasi Berprestasi) atau lebih dikenal dengan nama AMT (Achievement Motivation Training).

Menurut Hamzah (Purwanto, 2013), motivasi adalah suatu dorongan yang timbul oleh adanya rangsanganrangsangan dari dalam maupun dari luar, sehingga seseorang berkeinginan untuk mengadakan perubahan tingkah laku agar lebih baik. Ismail (Innayati, 2009) menguraikan motivasi yang mendorong seseorang untuk melakukan perbuatan antara lain: Quwwah Madiyah, Quwwah Ma'nawiyah, dan Quwwah Ruhiyah. Quwwah Madiyah, yaitu motivasi seseorang untuk memenuhi keperluan jasmani. Sedangkan yang dimaksud dengan Quwwah Ma'nawiyah, yaitu motivasi yang berupa kondisi kejiwaan yang senantiasa dicari seseorang. Selain itu, Quwwah Ruhaniyah, yaitu kesadaran seseorang bahwa ia memiliki hubungan dengan Allah SWT. Motivasi ruhiyah mampu mendorong seseorang untuk terus berikhtiar dan disertai tawakal, sehingga akhirnya mancapai keberhasilan dengan ijin Allah. Inilah motivasi berprestasi yang sesungguhnya.

Salah satu wujud motivasi adalah motif berprestasi. Usaha meningkatkan 
motivasi berprestasi dapat dilakukan PMB (Pelatihan Motivasi Berprestasi). PMB merupakan salah satu kegiatan pelatihan bagi peningkatan motivasi berprestasi (need for achievement) dalam diri seseorang. Kegiatan PMB memberikan kesadaran kepada seseorang untuk mengetahui potensi yang dimilikinya, serta memberikan semangat untuk berprestasi semaksimal mungkin. PMB didasarkan pada teori-teori motivasi yang dikembangkan oleh McClelland, yaitu motif bersahabat, motif berkuasa, dan motif berprestasi. Motivasi berprestasi merupakan suatu dorongan atau keinginan dalam diri untuk mencapai kesuksesan yang paling optimal, sehingga tercapai kecakapan pribadi yang tinggi (Slamet dkk, 2014). McClelland (1961) menyatakan bahwa Pelatihan Motivasi Berprestasi atau Achievement Motivation Training memberikan kontribusi yang signifikan untuk kemajuan masyarakat.

Berdasarkan penjelasan di atas, hipotesis yang diajukan dalam penelitian ini adalah ada perbedaan efikasi diri sebelum dan setelah dilakukannya pelatihan PMB (Pelatihan Motivasi Berprestasi).

\section{METODE PENELITIAN}

\section{Desain Penelitian}

Desain penelitian ini adalah penelitian kuasi dengan model one group pre- test dan post-test design (Saughnessy dkk, 2007), sebagai berikut:

Tabel. 1 Desain Eksperimen

\begin{tabular}{lll}
\hline O1 & X & O2 \\
\hline
\end{tabular}

Keterangan:

O1 : Pengukuran sebelum (pre-test)

$\mathrm{X}$ : Perlakuan/ treatment

O2 : Pengukuran setelah (post-test)

\section{Partisipan Penelitian}

Partisipan dalam penelitian ini sebanyak 173 mahasiswa kedokteran Universitas "Z". Pemilihan partisipan ditentukan melalui metode non random (tidak acak) Mereka adalah mahasiswa baru yang sudah diterima sebagai mahasiswa aktif Fakultas Kedokteran. Peserta dibagi menjadi empat kelas, sehingga masingmasing kelas berisi 43 atau 44 mahasiswa.

\section{Metode Pengambilan Data}

Skala yang digunakan dalam penelitian ini adalah skala efikasi diri yang diungkap berdasarkan ketiga dimensi yang diuraikan Bandura (2006), yaitu level, generality dan strenght. Level adalah suatu tingkat ketika seseorang meyakini tindakan yang dapat ia lakukan. Generality adalah keleluasaan dari bentuk efikasi diri yang dimiliki seseorang untuk digunakan dalam situasi yang berbeda. Strength adalah suatu kepecayaan diri yang terdapat dalam diri seseorang untuk 
mencapai tujuan tertentu. Hasil uji kung keberhasilan penelitian, yaitu terreliabilitas menunjukkan skala efikasi diri ini memiliki koefisien alpha 0,761.

Penyajian alternatif jawaban dalam skala efikasi diri disusun berdasarkan skala likert. Skala ini mengukur ketiga dimensi efikasi diri, di mana terdiri dari empat (4) jenjang penilaian dengan kategori jawaban yaitu sangat sesuai, sesuai, tidak sesuai dan sangat tidak sesuai.

\section{Prosedur Intervensi}

Pelatihan ini dilaksanakan dengan menggunakan metode pembelajaran andragogik, yaitu dengan cara melibatkan peserta pelatihan untuk aktif mengambil peran. Beberapa strategi pelatihan yang digunakan adalah presentasi, simulasi, studi kasus, role play, diskusi kelompok, analisa diri dan refleksi. Sarana pendusedianya media pela-tihan seperti ruang kelas, whiteboard \& alat tulis, LCD projector, laptop, sounds system, modul, dan lembar kerja.

Pelatihan ini dilaksanakan dengan cara single blind experiment, di mana subjek tidak mengetahui perlakuan apa yang akan didapatkan. Hal ini dimaksudkan agar mengontrol efek dari tuntutan karakteristik hingga diharapkan tidak memengaruhi hasil dari eksperimen tersebut. Peneliti tidak memberitahukan tujuan dari eksperimen, tetapi peneliti memberikan sedikit informasi mengenai eksperimen yang dilakukan (Myers \& Hansen, 2002).

Eksperimen ini, memberikan PMB sebagai perlakuan (treatment) dalam waktu dua hari. Jadwal pelatihan dapat dilihat pada Tabel 2. 
Tabel 2. Jadwal Kegiatan PMB

\begin{tabular}{|c|c|c|c|}
\hline Hari/ Waktu & Sesi & Durasi Waktu & Aktifitas \\
\hline \multicolumn{4}{|l|}{ Hari Pertama } \\
\hline & & 60 menit & Introduction \\
\hline & Sesi I & 110 menit & Materi build your inner motivation \\
\hline & & 10 menit & Coffee break \\
\hline & Sesi II & 120 menit & Materi knowing your self \\
\hline & & 60 menit & ISHOMA \\
\hline & Sesi III & 50 menit & Materi knowing your self \\
\hline & & 10 menit & Ice breaking \\
\hline & Sesi IV & 60 menit & Materi set your goal \\
\hline & & 30 menit & Istirahat \& sholat \\
\hline & Sesi V & 60 menit & Materi set your goal \& penutupan \\
\hline \multicolumn{4}{|l|}{ Hari Kedua } \\
\hline & & 30 menit & Pengkondisian Peserta \\
\hline & Sesi I & 80 menit & $\begin{array}{l}\text { Materi be proactive, change your } \\
\text { words }\end{array}$ \\
\hline & & 10 menit & Coffee break \\
\hline & Sesi II & 80 menit & Materi time and activity management \\
\hline & & 10 menit & Ice breaking \\
\hline & Sesi III & 30 menit & $\begin{array}{l}\text { Pengisian lembar kerja time and } \\
\text { activity management dan refleksi }\end{array}$ \\
\hline & & 60 menit & ISHOMA \\
\hline & Sesi IV & 90 menit & $\begin{array}{l}\text { Materi relaxation and stress } \\
\text { management }\end{array}$ \\
\hline & Sesi V & $\begin{array}{l}60 \text { menit } \\
30 \text { menit }\end{array}$ & $\begin{array}{l}\text { Deteksi stres dan latihan relaksasi } \\
\text { Istirahat \& Sholat }\end{array}$ \\
\hline & Sesi VI & 60 menit & $\begin{array}{l}\text { Self reflection (muhasabatun nafs) \& } \\
\text { penutupan }\end{array}$ \\
\hline
\end{tabular}

\section{Teknik Analisis Data}

Penelitian ini menghasilkan data kuantitatif yang diperoleh dari skor skala efikasi diri pada saat pre-test dan post-test. Metode analisis data yang digunakan adalah analisis statistik. Uji hipotesis dilakukan dengan menggunakan Wilcoxon Signed-Rank Test yang merupakan versi non-parametrik. Metode non-parametrik digunakan karena distribusi subjek tidak normal (Supranto, 2001)

\section{HASIL PENELITIAN}

Kategorisasi hasil pre-test dan post-test subjek penelitian dapat dilihat pada Bagan 1. 


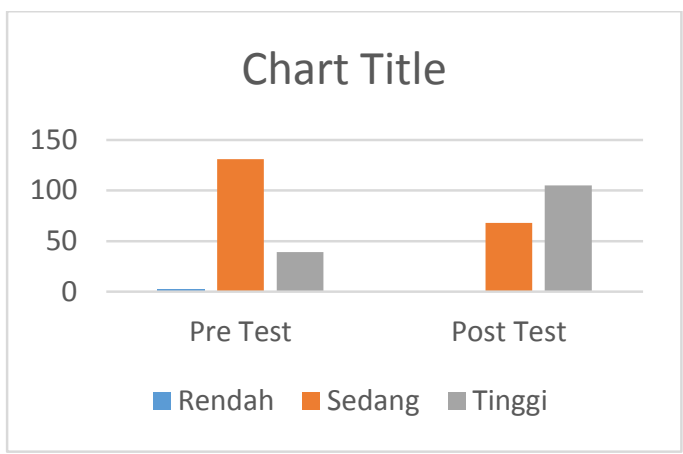

Bagan 1. Kategorisasi subjek penelitian saat pre-test dan post-test.
Secara lebih jelas, hasil tersebut di atas diuraikan dalam tabel 3 berikut:

Tabel 3. Kategorisasi partisipan

\begin{tabular}{lllllll}
\hline No & Skor & Prates & & Pascates & Kategorisasi \\
\hline & & $\mathrm{F}$ & $\mathrm{F} \%$ & $\mathrm{~F}$ & $\mathrm{~F} \%$ & \\
\hline 1 & $<20$ & 3 & $2 \%$ & 0 & $0 \%$ & Rendah \\
\hline 2 & $20<30$ & 131 & $76 \%$ & 68 & $39 \%$ & Sedang \\
\hline 3 & $>30$ & 39 & $23 \%$ & 105 & $61 \%$ & Tinggi \\
\hline
\end{tabular}

\section{Keterangan:}

$\begin{array}{ll}\text { Pre-test } & \text { : Sebelum pelatihan } \\ \text { Post-test } & \text { : Setelah pelatihan } \\ \mathrm{F} & \text { : Jumlah mahasiswa } \\ \mathrm{F} \% & \text { : Jumlah mahasiswa dalam bentuk persen (\%) }\end{array}$

Frekuensi menunjukkan jumlah responden yang memiliki skor skala efikasi diri tertentu. Pada kolom frekuensi, diketahui bahwa skor efikasi diri subjek dalam penelitian ini berada pada taraf rendah, sedang, dan tinggi pada saat sebelum mereka diberi pelatihan motivasi berprestasi. Setelah diberikan PMB, skor efikasi diri subjek berubah, sehingga hanya terkategorisasikan dalam tingkatan sedang dan tinggi. Tidak ada satupun subjek yang berada pada kategorisasi rendah.

Selain itu, rerata menunjukkan ratarata tingkat efikasi diri yang diukur dengan skala efikasi diri (model skala likert) dari 173 responden tersebut (sebelum pelatihan), yaitu 28.20 dan (setelah pelatihan) naik menjadi 31.80. Hal ini menandakan ada kenaikan 3.6 sebelum dan sesudah pelatihan. Hasil dapat dilihat pada tabel 4 . 
Tabel 4. Deskripsi statistik skor efikasi diri

\begin{tabular}{lcrrrr}
\hline Descriptive Statistics & N & Mean & Std. Deviation & Minimum & Maximum \\
\hline Pre Test & 173 & 28.20 & 3.792 & 18 & 40 \\
Post Test & 173 & 31.80 & 3.760 & 23 & 40 \\
\hline
\end{tabular}

Untuk menguji hipotesis, peneliti menggunakan perhitungan statistik Wilcoxon Signed-Rank Test. Adapun kaidah yang digunakan adalah apabila nilai $p<0.05$, maka terdapat perbedaan yang signifikan.

Hasil analisis menunjukkan bahwa terdapat perbedaan yang signifikan antara hasil pre-test dan post-test $(\mathrm{p}=0.000)$ pada partisipan penelitian. Adapun hasil analisis tersebut dapat dilihat pada Tabel. 5.

Tabel. 5

\begin{tabular}{llll}
\hline Sumber Data & Rerata & Z & P (2-tailed) \\
\hline Pre test- Post test & 3.6 & -10.058 & 0.000 \\
\hline
\end{tabular}

\section{PEMBAHASAN}

Tujuan dari penelitian ini adalah untuk mengetahui apakah terdapat pengaruh PMB terhadap peningkatan efikasi diri pada mahasiswa kedokteran. Hasil analisis menunjukkan hipotesis penelitian ada perbedaan efikasi diri sebelum dan sesudah PMB. Diterimanya hipotesis dalam penelitian ini menunjukkan bahwa PMB dapat meningkatkan efikasi diri pada mahasiswa kedokteran. Hal ini sesuai dengan yang diungkapkan oleh Bandura (1997) bahwa salah satu sumber informasi untuk meningkatkan efikasi diri seseorang adalah persuasi verbal.

Persuasi verbal merupakan informasi yang sengaja diberikan seseorang untuk mengubah efikasi dirinya, dengan cara memberikan dorongan semangat bahwa permasalahan yang dihadapi bisa diselesaikan. Penelitian ini, memberikan persuasi verbal dalam bentuk PMB kepada para mahasiswa untuk meningkatkan efikasi dirinya.

Dorongan semangat yang diberikan kepada orang yang mempunyai potensi dan terbuka menerima informasi akan menggugah semangat orang yang bersangkutan untuk berusaha lebih gigih meningkatkan efikasi dirinya. Semakin percaya seseorang kepada kemampuan pemberi informasi, maka akan semakin kuat keyakinan untuk mengubah efikasi diri (Rustika, 2012). PMB ini diisi oleh beberapa narasumber yang ahli di bidangnya, yaitu para psikolog dan dosen psikologi. Tentu hal ini memberi pengaruh pada cara penyampaian materi yang mampu membangkitkan semangat para mahasiswa kedokteran, terutama pada 
materi pertama yaitu "build your inner motivation".

Berbagai pencapaian manusia bermula dari motivasi. Motivasi adalah titik awal setiap prestasi. Motivasi juga merupakan faktor kunci penentu sukses dalam studi dan dalam berbagai bidang yang ditekuni. Oleh karena itu, motivasi yang kuat perlu dibangun sebagai landasan untuk mencapai puncak prestasi. Motivasi intrinsik perlu ditanamkan ke dalam suara hati dan akal sehat, agar dapat tetap selaras melangkah ke depan.

Hasil evaluasi peserta pada sesi build your inner motivation menunjukan bahwa sebanyak $70 \%$ mahasiswa merasa mampu meningkatkan motivasi dalam diri.

Dalam pelatihan PMB, pelatih memberikan materi "knowing your self", sebagai sarana untuk membantu para mahasiswa mengenali dirinya. Materi ini ternyata membawa pengaruh yang positif pada peningkatan efikasi diri seseorang. Bandura (1997) menyatakan bahwa persuasi verbal akan berhasil dengan baik apabila orang yang memberikan informasi mampu mendiagnosis kekuatan dan kelemahan orang yang akan ditingkatkan efikasi dirinya, serta mengetahui pengetahuan atau keterampilan yang dapat mengaktualisasikan potensi orang tersebut.

Oleh karena itu, di dalam pelatihan ini para peserta diajak untuk mengenali dirinya sendiri, sehingga mampu meng- optimalkan potensi mereka masingmasing. Selanjutnya hasil analisis pada sesi "knowing your self" menunjukkan bahwa sebanyak 59\% mahasiswa merasa bertambah pengetahuan tentang cara mengenali diri sendiri, sehingga mampu meningkatkan pemahaman diri.

Proses pengenalan diri merupakan bentuk optimalisasi salah satu sumber efikasi diri pengalaman pencapaian prestasi (Mutiara, 2010). Sesuai penelitian yang dilakukan Helmi (Mutiara, 2010) bahwa seseorang yang memiliki konsep diri positif akan lebih tepat dalam memberikan nilai keberadaannya, serta akan lebih percaya diri. Selain itu, sebagaimana dikatakan Johnson (Mutiara, 2010), apabila seseorang memiliki kesadaran diri yang lebih baik, maka akan semakin dapat mengontrol perilakunya dan semakin basar pula kemampuannya dalam beradaptasi pada situasi yang berubah-ubah. Hal ini akan menjaga persistensi efikasi diri yang telah terbentuk.

Materi ketiga yang diberikan dalam PMB yaitu "set your goal". Materi ini sangat penting, terutama bagi para mahasiswa kedokteran yang memiliki banyak tugas dan deadline, bahkan padatnya kegiatan praktikum. Pada dasarnya tingkat keberhasilan seseorang dalam mencapai tujuan sangat bergantung pada kemampuan individu dalam melaksanakan tugas. Dengan begitu, penyusunan 
tujuan ini akan membantu mahasiswa kedokteran untuk tetap fokus dan terus berusaha agar mampu menun-jukkan performa yang optimal.

Pada sesi "set your goal", hasil analisis data menunjukkan bahwa sebanyak $73 \%$ mahasiswa merasa bertambah pengetahuan tentang cara merancang tujuan. Para peserta umumnya menjadi dapat menetapkan tujuan dengan lebih sesuai situasi, dapat dicapai dan menjadi lebih mengerti cara untuk menetapkan tujuantujuan serta langkah-langkah konkrit dalam mencapainya. Proses ini terjadi melalui penetapan determinasi yang spesifik yang dapat meningkatkan keyakinan, motivasi dan persistensi yang merupakan komponen efikasi diri, dalam mencapai tujuan tertentu (Thompon dkk, 2002)

Saat seseorang memiliki tujuan yang jelas dalam hidupnya, maka ia lebih proaktif untuk mewujudkan cita-citanya. Oleh karena itu, dalam PMB ini para mahasiswa mendapatkan materi "be proactive, change your words". Pada sesi ini, analisis data menyatakan bahwa sebanyak 76\% mahasiswa bertambah pengetahuan untuk menjadi pribadi yang proaktif dan positif dalam berkata.

Peserta juga mendapatkan materi "time and activity management". Mengatur kegiatan, menata jadwal harian hingga mengelola berbagai peran menjadi realitas kehidupan mahasiswa kedokteran yang dinamis. Hasil analisis data menun- jukkan bahwa sebanyak $66 \%$ mahasiswa menjadi lebih paham tentang cara mengatur waktu dan kegiatan.

Padatnya jadwal kuliah dan praktikum jurusan kedokteran menuntut mahasiswa agar lebih pandai dalam mengelola waktu. Selain perlu memiliki keyakinan terhadap kemampuan dalam memecahkan masalah dan menyelesaikan tugas, para mahasiswa juga perlu memperhatikan waktu yang digunakan dalam melakukan berbagai aktivitas tersebut. Waktu merupakan sumber daya yang paling berharga sehingga diperlukan konsep manajemen waktu untuk menjaga keseimbangan antara tuntutan rutinitas dan kemampuan yang dimililikinya (Maulana, 2008).

Materi pelatihan yang diberikan kepada peserta lainnya yaitu "relaxation and stress management". Gumilar (Mutiara, 2010) menyatakan bahwa salah satu cara untuk meningkatkan efikasi diri adalah melalui relaksasi. Relaksasi merupakan salah satu metode yang banyak digunakan untuk mengurangi kecemasan agar lebih rileks (Davis dkk, 1995). Pada sesi ini, peserta belajar untuk mengurangi kecemasan sehingga lebih dapat percaya diri dan menjaga kestabilan emosi lebih baik. Hasil analisis data menyatakan bahwa sebesar $74 \%$ maha-siswa mampu mengelola waktu dan stres dengan lebih baik.

Sesi terakhir dalam PMB ini adalah "self reflection" atau muhasabatun nafs. 
Setelah seluruh rangkaian kegiatan dijalani, di akhir kegiatan peserta diajak untuk menyadari, menerima dan bertanggung jawab terhadap sumberdaya ilmu, motivasi, pengetahuan, sikap positif dan keterampilan yang bertambah. Kesadaran, penerimaan, pemaafan, dan kebersyukuran menjadi tema pokok dalam menutup seluruh rangkaian kegiatan. Para peserta mendapatkan motivasi ruhiyah yang mampu mendorongnya untuk terus berikhitiar dan disertai tawakal, sehingga pada akhirnya mereka akan mencapai keberhasilan atas ijin Allah. Inilah motivasi berprestasi yang sesungguhnya.

Faktor lain yang mendorong tercapainya peningkatan efikasi diri adalah cara trainer dalam menyampaikan materi pelatihan yang tidak monoton dan juga adanya ice breaking menjadikan peserta bersemangat mengikuti pelatihan, meskipun mereka telah lelah karena padatnya jadwal kegiatan. Peran aktif partisipan dalam PMB selama dua hari turut mendukung keberhasilan pelatihan.

\section{SIMPULAN DAN SARAN}

\section{Simpulan}

Berdasarkan hasil analisis yang dilakukan, terbukti adanya perbedaan antara skor pre-test dan post-test pada partisipan penelitian. Dengan demikian dapat disimpulkan bahwa PMB (Pelatihan
Motivasi Berprestasi) dapat meningkatkan efikasi diri pada mahasiswa kedokteran.

Meskipun hasil penelitian menunjukkan terdapat pengaruh yang signifikan antara PMB dengan meningkatnya efikasi diri pada mahasiswa, namun hasil ini tidak dapat digeneralisasikan karena pemilihan subjek yang non random.

\section{Saran}

Beberapa hal yang perlu dilakukan untuk perbaikan terhadap penelitian ini antara lain sebagai berikut. Pertama, peneliti selanjutnya mengupayakan randomisasi dalam memilih subjek penelitian. Kedua, Peneliti selanjutnya disarankan dapat mengkaji lebih dalam aspek spiritual, khususnya terkait penerapannya dalam konteks PMB. Materi yang bisa ditambahkan dalam pelatihan di antaranya penghayatan tentang syahadat, dan dzikir. Ketiga, sebaiknya peneliti selanjutnya melakukan pengukuran follow-up, sambil mengevaluasi pelaksanaan dari keteram-pilan PMB, sehingga mahasiswa mampu mempertahankan efikasi diri dirinya.

\section{DAFTAR PUSTAKA}

Bandura, A. (1997). Self-efficacy: The exercise of control. New York: W. H. Freeman and Company.

Bandura, A. (2006). Guide for constructing self-efficacy scales. Self-Efficacy 
Beliefs of Adolescents, 307-337. Diunduh pada 10 Juni 2017 dari http://www.uky.edu/ eushe2/Ban dura/BanduraGuide2006.pdf.

Baron. R.A. \& Byrne, D. (2004). Psikologi sosial Jilid I. Jakarta: Erlangga

Davis, M. Eshelman, E.R., \& McKay, M. (1995). The Relaxation \& stress reduction workbook ( $3^{\text {th }}$ ed). Jakarta: Penerbit Buku Kedokteran EGC.

Firmansyah, M.R. (2015, 24 Mei). Pendaftar UII Gelombang Lima Naik 11,85\%. Diunduh pada 8 Juni 2017, dari http://jogja.tribunnews. com/2015/05/24/pendaftar-uiigelombang-lima-naik-1185.

Innayati, E.M. (2009). Motivasi pengembangan sumber daya manusia dalam perspektif Islam. Jurnal MD. $2(1), 1$.

Luthans, F. (2006). Perilaku organisasi. Jogjakarta: Penerbit Andi.

Ma'arif, N. (2015, 15 Agustus). Pendaftar Meningkat, UII Membatasi Jumlah Mahasiswa Baru. Mahasiswa Baru. Diunduh pada 8 Juni 2017, dari http://lpmhimmahuii.org/2015/08/p endaftar-meningkat-uii-membatasijumlah-mahasiswa-baru/.

Maulana, A.M. (2008). 50 cara cerdas menggunakan waktu. Jawa Timur: Motivasi Arief.co.cc
McClelland, D. (1961). The achieving society. New York: The Free Press

Miladiyah, I., Rosita, L., \& Haris, A.A. (2010). Buku panduan akademik Fakultas Kedokteran 20102011.Yogyakarta: Universitas Islam Indonesia

Mu'tadin, Z. (2002). Penyesuaian diri remaja. Jakarta: Universitas Terbuka.

Mutiara, DNI., (2010). Keterampilan psikologis untuk meningkatkan efikasi diri pada pengguna napza di panti rehabilitasi. Jurnal Intervensi Psikologi. 2 (1), 1-136.

Myers, A. \& Hansen,C. (2002). Experimental psychology 5th edition. USA: Wadsworth Group.

Purwanto. (2013). Motivasi belajar dalam pendidikan Islam. Jurnal IImu Tarbiyah "At-Tajdid", 2(2), 221-236

Rumiani, (2006). Prokrastinasi akademik ditinjau dari motivasi berprestasi dan stres mahasiswa. Jurnal Psikologi Universitas Diponegoro, 3(2), 37-48.

Rustika, I.M. (2012). Efikasi diri: Tinjauan Albert Bandura. Buletin Psikologi, 20 (1-2), 18-25.

Santrock, J.W., (2007). Remaja (edisi 11 jilid 2). Jakarta: Erlangga.

Shaughnessy, J.J., Zechmeister, E.B., \& Zechmeister, J.S. Metode penelitian 
psikologi. Penerjemah Helly Prajitno Soetjipto dan Sri Mulyantini Soetjipto. Yogyakarta: Pustaka Pelajar.

Slamet, Pihasniwati, \& Hanifah, L.M. (2014). Program pelatihan motivasi berprestasi guna meningkatkan efikasi diri dan optimisme pada mahasiswa aktivis organisasi sebagai pengurus organisasi di “ Universitas Islam Negeri Sunan Kalijaga" Yogyakarta. Jurnal Psikologi Integratif. 2(2), 72-90.

Supranto, J. (2001). Statistik: Teori dan aplikasi. Jakarta: Erlangga.

Thompson, L.F., Meriac, J.P., \& Ope, J.G. (2002). Motivating online performance: The influence of goal setting and internet self sfficacy. Social Computer Review, 20, 149160

Universitas Islam Indonesia. (tanpa tanggal). Visi dan Misi. Diunduh pada 8 Juni 2017, dari https://www.uii.ac.id/visi-dan-misi/.

Vuong, M., Brown-Welty, S., \& Tracz, S. (2010). The effects of self-efficacy on academic success of firstgeneration College Sophomore studens. Journal of College Student Development, 5, 50-60.

Wijaya, I.P., \& Pratitis,N.T. (2012). Efikasi diri akademik, dukungan sosial orangtua dan penyesuaian diri mahasiswa dalam perkuliahan. Jurnal Persona. 1(1), 40-52. 


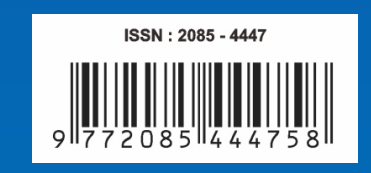

